\title{
Now Disease Reports \\ First report of Turnip yellow mosaic virus in Chinese cabbage and rocket in the Philippines
}

R.H. Reeder ${ }^{1}$, S. Edgington ${ }^{1}$, N.S. Baucas ${ }^{2}$, R.C. Joshi ${ }^{3}$, M.A.G. Bas-ilan ${ }^{2}$, A. Skelton ${ }^{4}$, A. Fowkes ${ }^{4}$, V. Harju $^{4}$, R. Ward ${ }^{4}$, M. $^{2}$ Kelly ${ }^{4}$, A. Buxton Kirk ${ }^{4}$, S. Forde ${ }^{4}$, A. Fox ${ }^{4}$ and S. Annamalai ${ }^{5}$

${ }^{1}$ CABI Bioscience, Bakeham Lane, Egham, Surrey TW20 9TY, UK; ${ }^{2}$ DA-RFO-CAR, BPI compound, Guisad, Baguio City, Philippines ; ${ }^{3}$ Pampanga State Agricultural University, PAC Magalang, Pampanga, Philippines; ${ }^{4}$ Fera Science Ltd., Sand Hutton, York YO41 1LZ, UK; ${ }^{5}$ CABI, P.O. Box 210, Serdang, Selangor, Malaysia

*E-mail: r.reeder@cabi.org

Received: 06 Aug 2017. Published: 16 Sep 2017.

In 2012, vegetable farmers in the Philippine highlands (Buguias and Benguet provinces) first observed unusual yellowing symptoms in Chinese cabbage (Brassica rapa subsp. pekinensis) planted in their fields. The symptoms were pronounced vein clearing, vein yellowing and a bright yellow mosaic. Similar symptoms were again seen in 2013 with more farmers reporting serious crop losses. The Benguet State University Plant Pest Clinic initially identified the problem as a viral disease but were unable to identify the cause further. The disease continued to affect farmers in subsequent years and in a varietal field trial conducted from October 2015 to February 2016 the incidence ranged from 10-32\%.

In January of 2017 during a field visit to the provinces of Buguias and Benguet, virus-like symptoms were observed on Chinese cabbage (Figs. 1-3), rocket (Eruca sativa; Fig. 4), cabbage (Brassica oleracea), pak choi (Brassica rapa subsp. chinensis) and radish (Raphanus raphanistrum subsp. sativus). In addition to the virus symptoms the plants were observed to be heavily infested with adult striped flea beetle (Phyllotreta striolata). The viral disease was widespread on Chinese cabbage infecting approximately $25 \%$ of the crop (Fig. 5).

Symptomatic leaves were taken from the brassicaceous plants at 17 sampling locations. In total leaves from 48 Chinese cabbage plants were selected as well as leaves from individual plants of pak choi, rocket, radish and cabbage. The leaf samples were packaged up and sent to the Diagnostic and Advisory Service, CABI, UK for further analysis. On examination the samples were subsequently forwarded onto Fera Science Ltd for virus testing.

The dried samples were bulked together for virus testing using ELISA. All samples tested negative for known viruses of Brassicaceae, such as Cucumber mosaic virus, Turnip mosaic virus and Turnip yellows virus. However, the bulked sample was positive for Turnip yellow mosaic virus (TYMV, genus Tymovirus). In order to ascertain how widespread the virus was, representative leaf samples from each host at each location were tested for TYMV individually using ELISA. All of the leaf samples of Chinese cabbage tested positive as did one sample of rocket. However, there were no positives for TYMV for leaf samples of cabbage, pak choi or radish. To confirm the ELISA results several of the samples were tested by RTPCR using a TYMV primer set (Lee \& Rho, 2015). Amplicons of the expected size were detected (491 bp) in all the Chinese cabbage samples tested and the rocket sample. The PCR products for one of the Chinese cabbage samples and the rocket sample were sent for sequencing. Consensus sequence data was obtained using Mega 4.1 software. Nucleotide sequences were compared by searching the BLASTn database, confirming TYMV in both samples (95\% nucleotide sequence identity to GenBank Accession No. X07441). The sequences were added to GenBank (MF576298, Chinese cabbage; and MF576299, rocket).

TYMV is confined almost entirely to the Brassicaceae family, and has been reported in the former Czechoslovakia, Italy, Spain, UK, Japan, Canada, Australia and New Zealand. However, to the best of the authors' knowledge this is the first report of this virus in the Philippines. The virus is seed transmitted with relatively low rates of transmission $(2.5-2.9 \%)$ (AlfaroFernández et al., 2016) and this may have been how it arrived in the Philippines. Transmission in the field is by flea-beetles, species of Phyllotreta and Psylliodes, and the mustard beetle (Phaedon cochleariae) including its larvae. Future studies to investigate the transmission and management options for the virus in the Philippines are being planned.

\section{References}

Alfaro-Fernández A, Serrano A, Tornos T, del Carmen Cebrián M, del Carmen Córdoba-Sellés M, Jordá C, Font MI, 2016. Turnip yellow mosaic virus in Chinese cabbage in Spain: commercial seed transmission and molecular characterisation. European Journal of Plant Pathology 146, 433-442. http://dx.doi.org/https://doi.org/10.1007/s10658-016-0929-3 Lee S, Rho JY, 2016. Development of a specific diagnostic system for detecting Turnip yellow mosaic virus from Chinese cabbage in Korea. Indian Journal of Microbiology 56, 103-107. http://dx.doi.org/https://doi.org/10.1007/s12088-015-0557-1

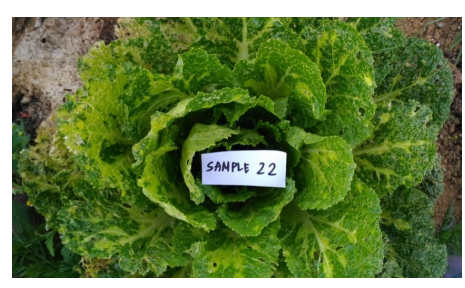

Figure 1

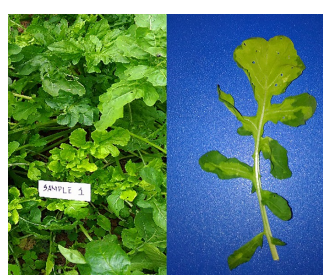

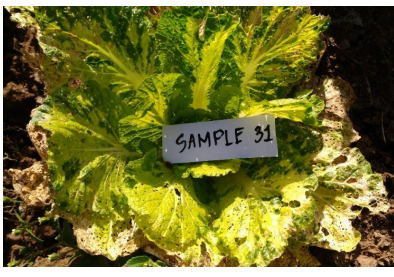

Figure 2

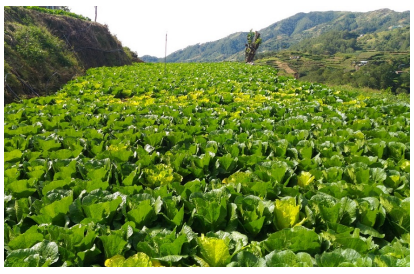

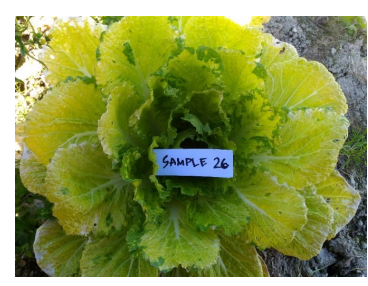

Figure 3

Figure 5

To cite this report: Reeder RH, Edgington S, Baucas NS, Joshi RC, Bas-ilan MAG, Skelton A, Fowkes A, Harju V, Ward R, Kelly M, Buxton Kirk A, Forde S, Fox A, Annamalai S, 2017. First report of Turnip yellow mosaic virus in Chinese cabbage and rocket in the Philippines. New Disease Reports 36, 8. http://dx.doi.org/10.5197/j.2044-0588.2017.036.008 